Vania Cynthia, Rahmadani Yusran I Evaluasi Program Desaku Menanti dalam Penanggulangan Gelandangan dan Pengemis di Kota Padang

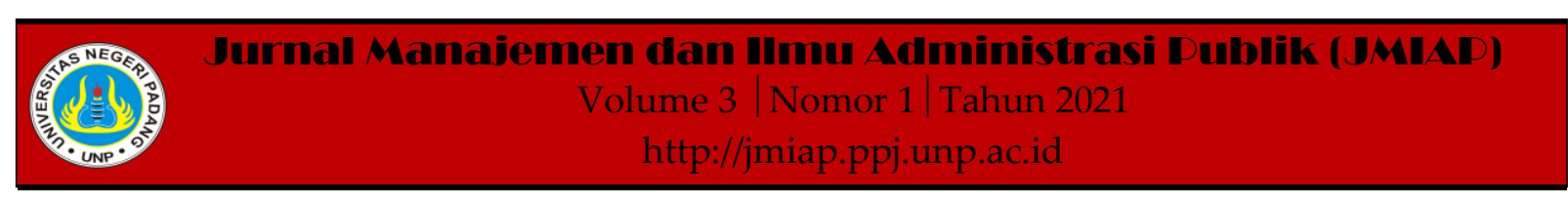

\title{
EVALUASI PROGRAM DESAKU MENANTI DALAM PENANGGULANGAN GELANDANGAN DAN PENGEMIS DI KOTA PADANG
}

\author{
Vania Cynthia $^{1(a)}$, Rahmadani Yusran ${ }^{2(b)}$ \\ ${ }^{1}$ Jurusan Ilmu Administrasi Negara, Universitas Negeri Padang \\ ${ }^{2}$ Jurusan Ilmu Administrasi Negara, Universitas Negeri Padang \\ a)vaniacynthiaa@gmail.com, ${ }^{b)}$ yusranrdy@fis.unp.ac.id
}

ABSTRACT - This study aims to analyze the evaluation of the Desaku Menanti Program in dealing
with homeless people and beggars in the city of Padang. The basis for the implementation of the my
village program is regulated in the Padang City Regional Regulation Number 1 of 2012 concerning
Development of Street Children, Homeless People, Beggars, Singers and Street Vendors. The objectives
of the village waiting program are 1) Improving people's ability to carry out their social functions
properly in society. 2) Improve the ability of people and the social environment to solve social problems.
3) Improving people's social status and roles so that they can adapt to their environment. This program
is an innovation of the programs for handling the homeless, beggars and street children that have been
carried out, namely by focusing all services in the areas of origin of homeless people and beggars
(village based). This research is a qualitative research using descriptive method. The research
informants were determined by purposive sampling. Data collection techniques are carried out by
conducting interviews, observations, and documentation studies and data reduction is carried out so
that accurate conclusions can be drawn from the data that has been obtained. The results showed that
the impact of the implementation of the Desaku Menanti program in dealing with homeless people and
beggars in the city of Padang was not optimal. This is because the objectives of the Desaku Menanti
program have not been achieved.
Keywords : Policy Evaluation, Vagabonds and Beggars, Desaku Menanti Program
Corresponding author. Email. vaniacynthiaa @ gmail.com
How to cite this article. Cynthia, V \& Yusran, R. (2021). Evaluasi Program Desaku Menanti dalam
Penanggulangan Gelandangan dan Pengemis di Kota Padang. Jurnal Manajemen dan Ilmu Administrasi
Publik (JMIAP) Jurusan Ilmu Administrasi Negara Fakultas Ilmu Sosial Universitas Negeri Padang,
Volume 3 (1), Hal. 39-46.
http://jmiap.ppj.unp.ac.id
Copyright@2021. Published by Labor Jurusan Ilmu Administrasi Negara FIS UNP, Padang 


\section{PENDAHULUAN}

Kemiskinan merupakan suatu keadaan seseorang yang tidak mampu mencukupi kebutuhan hidupnya, kemiskinan ini masih menjadi permasalahan sosial yang belum dapat diatasi saat ini karena masih ditemukan dikehidupan masyarakat. Kota Padang sebagai ibu kota provinsi tidak bisa dipisahkan dari keberadaan pengemis. Permasalahan glandangan dan pengemis ini dapat dikatakan tidak jauh dari permasalahan kemiskinan, keadaan ini terjadi dimana suatu individu yang tidak mampu memenuhi kehidupan sehariharinya, seperti makanan, kesehatan, pakaian, pendidikan dan tempat tinggal yang layak. Maka dalam hal ini Kementrian Sosial dalam Direktorat Rehabilitasi Sosial Tuna Sosial membuat suatu model penanganan gepeng yaitu Program Desaku Menanti. Adapun tujuan dari pelaksanaan program ini adalah: 1)Memperbaiki kemampuan orang untuk melaksanakan fungsi sosialnya secara wajar dalam masyarakat. 2)Memperbaiki kemampuan orang dan lingkungan sosial dalam memecahkan masalah-masalah sosial. 3)Memperbaiki status dan peranan sosial orang sehingga dapat menyesuaikan diri dengan lingkungannya.

Khususnya di Kota Padang Perda yang menjadi dasar pelaksanaan program desaku menanti terdapat dalam Perda Kota Padang Nomor 1 Tahun 2012 tentang Pembinaan Anak Jalanan, Gelandangan, Pengemis, Pengamen dan Pedagang Asongan. Program ini khususnya diberikan kepada gepeng yang masih produktif. Lokasi Program Desaku Menanti di kota Padang ini yaitu di Kampung Kesetiakawanan Sosial Saiyo Sakato, jalan Balai Gadang, Air Dingin Lubuk Minturun, Kelurahan Balai Gadang, Kecamatan Koto Tangah. Program Desaku menanti ini diresmikan pada tanggal 9 Maret 2017 di Kota Padang yang diresmikan langsung oleh Menteri Sosial Republik Indonesia, ditandai dengan 40 rumah yang akan diberikan kepada warga binaan sosial. Sebelum ditempatkan warga eks gepeng terlebih dahulu diberikan pelatihan dan bimbingan edukasi oleh Dinas Sosial kota Padang, tidak hanya itu mereka juga dibeerikan bantuan modal sebanyaak 5 juta rupiah oleh Dinas sosial. (Singgalang, 2018) Beberapa aktor yang terlibat dalam penyelenggaraan Program Desaku Menanti di Kota Padang yaitu Dinas Sosial, eks gepeng, LKS, PSM dan aktor-aktor yang membantu dalam penyelenggara program.

Pada temuan dilapangan bahwasannya evaluasi program Desaku Menanti dalam penanggulangan gelandangan dan pengemis di Kota Padang belum dapat memberikan dampak signifikan. Hal ini dikarenakan, Pertama, belum optimalnya pengawasan, hal ini dilihat dari adanya rumah yang kosong tidak ada penghuninya, ternyata warga yang menempati rumah itu kabur dan tidak betah tinggal dikampung tersebut, yang menjadi alasan mereka kabur karena jauh dari tempat bekerja yang berada di kota. Permasalahan kedua adalah pelatihan yang diberikan tidak sepenuhnya dimengerti oleh wbs dan hasil pelatihan keterampilan tersebut tidak disediakan tempat pemasarannya sehingga pelatihan ini tidak bisa dikembangkan oleh warga binaan. Permasalahan ketiga adalah, transportasi yang sulit dijangkau karena rata-rata warga binaan sosial bekerja di pusat kota, jarak tempuh dari kampung tersebut ke kota lumayan jauh, akibatnya penghasilan yang didapatkan hanya abis di ongkos saja dan peningkatan hidup belum berubah. Permasalahan ke empat adalah, belum adanya air bersih, walaupun disana sudah ada air pamsimas tetapi hal ini belum sepenuhnya memenuhi kebutuhan warga binaan sosial karena jika terjadinya hujan air pamsimas tersebut akan berubah menjadi keruh dan tersumbat.

\section{TINJAUAN PUSTAKA Konsep Kebijakan Publik}

Nugroho R (dalam Sore dan Sobirin, 2017:8) mengatakan bahwa kebijakan publik merupakan suatu aturan yang harus ditaati bersama, namun lembaga yang berwenang akan menjatuhkan sanksi jika 
kedapatan ada yang melanggar dan sanksi yang diberikan sesuai dengan pelanggaran yang dilakukannya.

Menurut Dunn (1999:132) kebijakan publik merupakan suatu rangkaian peraturan-peraturan yang telah direncanakan terlebih dahulu dan perundang-undangan merupakan sebagai acuan formal dalam melakukan suatu tindakan yang dibuat oleh pemerintah.

Lester \& Stewart dalam Agustino (2008: 196) implementasi kebijakan merupakan suatu tahap dalam melakukan penyelenggaraan peraturan kebijakan yang telah ditetapkan terlebih dahulu menjadi undang-undang. Dan sebagai pengadministrasian suatu undang-undang berdasarkan prosedur, aktor, organisasi dan teknik bekerjasama dalam mencapai suatu tujuan yang telah ditentukan.

\section{Konsep Implementasi Kebijakan Publik} Menurut Tacjhan (2006:25) Implementasi kebijakan publik ialah suatu proses administratif yang terletak pada perumusan dan evaluasi kebijakan, hal ini dapat dilaksanakan setelah kebijakan tersebut disetujui. Implementasi kebijakan memiliki logika top-down yang artinya menafsirkan yang masih asbtrak menjadi suatu yang konkrit. Sedangkan formulasi kebijakan memiliki logika buttom-up yang artinya suatu proses yang dimulai dari pemetaan kebutuhan publik yang kemudian diiringi dengan pencarian cara mengatasinya, dan selanjutnya diusulkan untuk diresmikan.

Mulyadi (2016:56-57) mengatakan implementasi kebijakan publik ialah Suatu tahap yang harus diimplementasikan terlebih dahulu agar dapat melihat tujuan atau dampak yang diharapkan. Implementasi kebijakan dilakukan oleh formulasi kebijakan yang diawali sebelum sasaran dan tujuan diresmikan. Dengan begitu, tahap kebijakan implementasi dilakukan setelah undang-undang diresmikan dan setelah dana yang disediakan untuk implementasi kebijakan tersebut.
Menurut Winarno (2007:77) Kebijakan publik merupakan suatu alat yang dapat mengatasi masalah yang ada dalam pemerintahan, masalah publik ini terjadi karena akibat dari orang-orang yang secara langsung terlibat maupun yang secara tidak langsung terlibat.

\section{Konsep Evaluasi Kebijakan Publik}

Menurut Dunn (1999:608), Evaluasi merupakan nilai dan hasil dari kebijakan. Hasil kebijakan mempunyai nilai tersendiri oleh karena itu hasil tersebut merujuk pada sasaran dan tujuan kebijakan tersebut. Dengan begitu kebijakan atau program yang telah mencapai suatu tujuan yang diinginkan maka kebijakan yang telah dibuat sudah jelas dan dapat mengatasi masalah-masalah kebijakan tersebut.

Lester dan Stewart (2000:126) dalam (Agustino. 2008:185) memiliki pendapat yang sedikit berbeda dengan Dunn. Lester dan Stewart mengatakan bahwa evaluasi merupakan suatu cara yang dapat melihat atau menilai kebijakan tersebut berhasil atau tidak dan dapat mengetahui kebijakan yang telah dirumuskan serta dapat menghasilkan suatu dampak yang diinginkan. Pendapat Lester dan Stewart dipertegas dengan pendapat yang hampir sama, yang dikemukakan oleh Indiahono (2009:145), menurutnya evaluasi kebijakan publik adalah dapat menilai berhasil atau gagalnya suatu kebijakan.

Evaluasi merupakan suatu proses identifikasi yang digunakan menilai apakah suatu program dijalankan sesuai perencanaan dan apakah berhasil dalam mencapai tujuan atau tidak. Evaluasi kebijakan tidak terlepas dari proses implementasi kebijakan dalam program tertentu. Perhatian terhadap implementasi perlu diperhatikan karena berkaitan erat dengan aktivitas menilai kesesuaian antara tujuan dan pelaksanaan kebijakan (Aprina. Y \& Yusran. R. 2020); aktivitas kelompok dalam melaksanakan program kebijakan (Handika V, Yusran R. 2020); mengetahui hasil fungsi sosial kebijakan (Fitri, S. Yusran, R. 2020). Dengan mengetahui 
implementasi suatu kebijakan dapat dilakukan evaluasi ketercapaian tujuan dan manfaat suatu kebijakan.

\section{Konsep Gelandangan dan Pengemis}

Menurut Peraturan Pemerintah Republik Indonesia Nomor 31 Tahun 1980 tentang Penanggulangan Gelandangan dan Pengemis, gelandangan yaitu seseorang yang kehidupan sehari-harinya tidak layak atau tidak sesuai dengan norma kehidupan yang semestinya, seperti tidak memiliki pekerjaaan tetap dan tempat tinggal. Pengemis adalah sesorang yang tidak mau bekerja keras dan memenuhi kebutuhan hidupnya dengan cara meminta-minta serta berharap dikasihani oleh orang lain di depan umum.

Menurut Suparlan (1993:179) gelandangan artinya berpindah-pindah tempat dan tidak memiliki kediaman yang tetap. Para gelandangan tersebut ialah orang-orang yang asalnya dari desa bertujuan untuk mencari pekerjaan di kota, namun tingkat pendidikannya yang tidak cukup dan tidak mempunyai bakat atau keahlian sendiri yang mengakibatkan mereka bekerja serabutan, seperi pengemis, pemulung dan pengamen.

\section{Konsep Program Desaku Menanti}

Program Desaku Menanti merupakan program rehabilitasi sosial untuk menangani gelandangan dan pengemis yang berbasis desa. Program ini dapat meningkatkan kesejahteraan sosial karena bantuan yang diberikan seperti rumah layak huni sementara, pelatihan keterampilan dan bantuan modal usaha. Dengan adanya program ini para eks gepeng dapat meningkatkan taraf hidup mereka.

\section{Penelitian Terdahulu}

Penelitian ini berbeda dengan penelitian Ifni Amanah Putri dengan kajian Penanggulangan Gelandangan dan Pengemis di Indonesia (Analisis Program Desaku Menanti di Kota Malang, Kota Padang dan Jeneponto) metode penelitian yang dilakukan dalam penelitiannya yaitu menggunakan metode studi literature yang mencari data-data melalui surat kabar maupun internet. Sedangkan penulis menggunakan metode penelitian kualitatif yang bersifat deskriptif. Dan teknik pengumpulan data dilakukan dengan wawancara, observasi maupun dokumentasi yang mana dapat menghasilkan data yang lebih akurat.

\section{METODE PENELITIAN}

Penelitian ini kualitatif yang menggunakan metode deskriptif. Lokasi penelitian ini dilaksanakan di Kampung Kesetiakawanan Sosial Kelurahan Balai Gadang. Teknik pengumpulan data dilakukan dengan melakukan wawancara, observasi, maupun studi dokumentasi, lalu dilakukan reduksi data agar bisa menarik kesimpulan yang akurat dari data yang telah didapat.

\section{HASIL DAN PEMBAHASAN \\ Pelaksanaan Program Desaku Menanti dalam Penanggulangan Gelandangan dan Pengemis di Kota Padang}

Dalam pelaksanaan program desaku menanti, berdasarkan perda inilah yang menjadi dasar pelaksana program tersebut yaitu terdapat pada Peraturan Daerah Kota Padang Nomor 1 Tahun 2012 tentang Pembinaan Anak Jalanan, Gelandangan, Pengemis, Pengamen dan Pedagang Asongan.

Kegiatan pelaksanaan yang dilakukan pada program yaitu pertama, bimbingan fisik mental dan sosial, pembinaan terlebih dahulu tujuannya untuk merubah pola pikirnya dan menyadarkan orang-orang tersebut agar tidak hidup dengan memintaminta. Hal ini sudah dilakukan sesuai dengan pelaksanaanya namun untuk merubah pola pikirnya dan sikap mental para gelandangan dan pengemis ini sulit dilakukan karena pada dasarnya para gelandangan dan pengemis dari dalam dirinya mempunyai sifat malas bekerja keras. Kedua, pelaksanaan pelatihan keterampilan yang sudah dilakukan. Para warga binaan sosial kemudian mendapatkan pelatihan keterampilan. Pelatihan 
keterampilan yang sudah dilakukan tahun ini yaitu membuat kue dan karangan bunga. Biaya pelatihan yang ditanggung oleh Pemerintah Pusat maupun Pemerintah Daerah. Tujuan dari pelatihan keterampilan ini yaitu untuk meningkatkan kemampuan dan keterampilan warga binaan sosial, dan mendorong warga binaan sosial untuk berwirausaha dengan begitu mereka akan terbiasa hidup mandiri serta dapat meningkatkan perekonomian mereka. Namun anggaran APBD ini terbatas, maka terbatas pula pelaksanaan pelatihan keterampilan yang dilakukan dan hal ini berpengaruh dalam kemajuan program yang dijalankan. Ketiga, bantuan usaha ekonomi produktif (UEP) dan jadup, bantuan ini sudah diberikan secara menyeluruh kepada warga binaan sosial Selain pelatihan keterampilan, mereka juga diberikan modal untuk usaha. Bantuan UEP ini diberikan kepada warga binaan sosial sebesar Rp.5.000.000. Bagi yang telah mendapatkan bantuan harus menandatangani surat perjanjian tujuannya agar mereka tidak menggelandang atau mengemis lagi. Selain itu warga binaan sosial juga diberikan jaminan hidup. Jaminan hidup hanya diberikan saat tahun pertama selama 3 bulan, senilai 100.000 per hari, selain itu ada juga bantuan keperluan rumah tangga sebesar Rp. 1.500.000. danbantuan keterampilan yang dilaksanakan selama 15 hari. Tujuan bantuan ini diberikan agar warga binaan sosial dapat mengembangkan keterampilan dengan modal usaha yang diberikan.

Keempat, bantuan bahan baku rumah. Dalam pelaksanaan Program Desaku Menanti warga binaan sosial diberikan rumah dan fasilitas lengkap untuk ditempati selama 5 tahun. Dinas sosial menyediakan 40 unit rumah untuk warga binaan sosial dan mendapatkan dukungan dari berbagai pihak yaitu baik Pemerintah Pusat, Pemerintah Kota, Lembaga Kesejahteraan Sosial (LKS) Yayasan Rahmah, PSM, maupun relawan-relawan masyarakat luas sehingga mempermudah pelaksanaan program. Namun, beberapa rumah terlihat kosong tidak berpenghuni karena warga binaan sosial tidak tinggal di rumah yang telah diberikan dengan alasan jauh dari tempat bekerja yang berada di pusat kota. Rumah yang kosong tersebut langsung digembok oleh pihak Dinas Sosial. Hal ini bisa dikatakan bahwa kurangnya pengawasan terhadap warga binaan sosial. Hasil penelitian menunjukkan bahwa evaluasi program ini belum optimal dilaksanakan karena masih terkendala dalam beberapa indikator, seperti: Pertama, sumber daya anggaran, dengan keterbatasan anggaran APBD ini maka terbatas pula pelaksanaan pelatihan keterampilan yang dilakukan dan berpengaruh dalam kemajuan program yang dijalankan. Kedua, sumber daya manusia terbatas karena hanya satu orang PSM yang bekerja untuk mengawasi sekaligus pendamping warga binaan sosial. Hal ini mengakibatkan beberapa rumah terlihat kosong tidak berpenghuni dikarenakan kurangnya pengawasan.

\section{Dampak Kebijakan Program Desaku Menanti dalam Penanggulangan Gelandangan dan Pengemis di Kota Padang}

Dalam melihat bagaimana bentuk dampak kebijakan Program Desaku Menanti dalam penanggulangan gelandangan dan pengemis di Kota Padang penulis melakukan penelitian khususnya pada Dinas Sosial Kota Padang. Kegiatan pelaksanaan yang dilakukan pada program desaku menanti yaitu :

1) Melakukan Pembinaan

Eks gepeng yang terpilih atau lolos seleksi maka akan diberikan pembinaan seperti bimbingan sosial, fisik dan mental. Djumhur dan Moh. Surya (Tohirin.2007:126) mengatakan bimbingan sosial ini tujuannya untuk seseorang yang sedang mengalami permasalahan sosial, hal ini dapat mengatasi kesulitan-kesulitan masalah sosial dan dapat memecahkan masalahnya, dengan demikian seseorang tersebut dapat menyesuaikan diri dengan baik dalam kehidupan sosialnya. 
Tujuan pembinaan ini dilakukan untuk merubah pola pikirnya dan menyadarkan orang-orang tersebut agar hidup mandiri tanpa meminta-minta. Dampak pelaksanaan pembinaan ini yaitu para warga binaan sosial yang dahulunya gelandangan dan pengemis sekarang sudah ada perubahan dari kehidupannya, seperti sudah mendapatkan penghasilan dari pekerjaannya. Walaupun warga binaan sosial sudah mempunyai penghasilan sendiri namun tidak seluruhnya merasakan hal yang sama karena masih adanya warga yang masih belum mendapatkan pekerjaan. Karena pada dasarnya para gelandangan dan pengemis dari dalam dirinya mempunyai sifat malas bekerja keras.

\section{2) Pelaksanaan Pelatihan Keterampilan}

Secara umum pengertian keterampilan ialah kemampuan seseorang dalam menggunakan kreatifitas, ide, akal dan pikiran dalam membuat sesuatu kemampuan menjadi suatu hal yang bermakna dan menghasilkan nilai tersendiri dari hasil pekerjaan yang telah dilakukan.

Dengan adanya pemberian pelatihan kepada warga binaan sosial tersebut diharapkan mampu meningkatkan kemampuan dan keterampilan mereka sehingga dapat mengubah pola pikirnya dan menyadarkan mereka agar tidak menggelandang dan mengemis lagi, hal ini dapat mendorong warga binaan sosial tersebut untuk berwirausaha dengan begitu mereka akan terbiasa hidup mandiri dan dapat meningkatkan perekonomian mereka. Berdasarkan temuan di lapangan dapat dilihat bahwa usaha yang telah dilakukan Dinas Sosial sudah cukup maksimal walaupun kenyataannya warga binaan sosial ada yang belum mengerti dengan pelatihan yang diberikan dan juga tidak diberikan tempat pemasaran sehingga pelatihan tersebut tidak dapat dikembangkan lebih lanjut. Dengan demikian peneliti mengatakan untuk mencapai hasil yang diinginkan belum efisien.
3) Bantuan Usaha dan Jaminan Hidup

Bantuan usaha ekonomi produktif (UEP) dan jaminan hidup ini dilakukan untuk modal usaha dan unutuk memenuhi kebutuhan sehari-hari para warga binaan sosial.

Dampak dari bantuan usaha ekonomi produktif dan jaminan hidup ini adalah warga binaan sosial terbantu dengan adanya bantuan ini dan warga binaan sosial dapat mengembangkan keterampilan dengan modal usaha yang diberikan. Namun berdasarkan temuan dilapangan peneliti menemukan warga binaan sosial tidak mengembangkan bantuan usaha yang diberikan dan membelanjakan bantuan tersebut. Hal ini dapat dikatakan bahwa bantuan dana yang diberikan kepada warga tidak bisa dimanfaatkan dengan sebaikbaiknya untuk mengembangkan usaha mandiri karena ditemukan warga binaan sosial menggunakan dana bantuan tersebut habis untuk memenuhi kebutuhan hidup sehari-hari.

\section{4) Bantuan Bahan Baku Rumah}

Bantuan rumah ini diberikan agar warga binaan sosial memiliki tempat tinggal yang layak dan tidak memikirkan tempat tinggal lagi. Dan juga dilengkapi dengan fasilitas, rumah tersebut ditempati warga binaan sosial selama 5 tahun. Yang menjadi dampak bantuan rumah ini yaitu jarak tempuh rumah yang jauh dari kota karena kebanyakan dari warga binaan sosial bekerja di arah kota. Akibatnya penghasilan yang didapatkan habis diongkos karena tidak semua warga binaan sosial yang memiliki kendaraan pribadi. Lalu sebagian dari warga binaan sosial ada yang kabur dari kampung tersebut alasannya karena tidak betah dan jauh dari tempat ia bekerja, rumah yang diberikan tersebut kosong ditinggalkan begitu saja. Pihak dinas sosial pun langsung menggembok rumah yang tidak dihuni tersebut. Tidak hanya itu rumah yang diberikan tersebut ternyata tidak dilengkapi dengan air bersih. Walaupun sudah ada air pamsimas, namun air pamsimas tersebut digunakan secara 
bergiliran, selain itu jika terjadi hujan airnya menjadi keruh dan tersumbat. Pihak Dinas Sosial sudah berupaya agar pihak PDAM secepatnya menyalurkan air bersih ke kampung kesetiakawanan saiyo sakato tetapi sampai saat ini belum ada perkembangan. Dengan demikian hal ini belum menjawab kebutuhan masyarakat.

\section{PENUTUP}

Berdasarkan hasil evaluasi yang telah dilakukan, pelaksanaan program desaku menanti di Kota Padang ditinjau dari aspek pencapaian tujuan program belum optimal karena masih ditemukan warga binaan sosial yang belum bekerja. Lalu pelatihan keterampilan yang diberikan tidak dapat di pasarkan karena tidak diberikan tempat pemasaran sehingga pelatihan tersebut tidak dapat dikembangkan lebih lanjut, masih ditemukan warga binaan sosial yang tidak menempati rumah yang telah diberikan dan air bersih sampai saat ini tidak tersedia di kampung tersebut.

\section{DAFTAR KEPUSTAKAAN}

Agustino, Leo. 2008. Dasar Dasar Kebijakan Publik. Bandung: Alfabeta.

Dunn, William N. 1999. Analisis Kebijakan Publik. Yogyakarta: Gadjah Mada University Press.

Indiahono, Dwiyanto. 2009. Kebijakan Publik Berbasis Dynamic Policy Analisys. Yogyakarta: Gava Media.

Mulyadi, Deddy. 2016. Studi kebijakan publik dan pelayanan publik. Bandung: Alfabeta.

Sore, Uddin B dan Sobirin. 2017. Kebijakan Publik. Makassar: CV. Sah Media.

Suparlan, Parsudi. 1993. Kemiskinan di Perkotaan. Jakarta: Yayasan Obor Indonesia.

Tachjan. 2006. Implementasi Kebijakan Publik. Bandung: Asosiasi Ilmu Politik Indonesia.
Tohirin. (2007). Bimbingan dan konseling di sekolah dan madrasah (Berbasis Integrasi). Jakarta: PT Raja Grafindo Persada.

Fitri, Ifni Amanah. 2019. Penanggulangan Gelandangan dan Pengemis di Indonesia (Analisis Program Desaku Menanti di Kota Malang, Kota Padang dan Jeneponto). Social Work Jurnal Vol. 9, No. 1.

Aprina, Y., \& Yusran R. (2020), implementasi peraturan daerah kota bukittinggi nomor 2 tahun 2015 tentang pencegahan dan penang-gulangan bahaya kebakaran. Jurnal mahasiswa ilmu administrasi publik, 1(4), 87-97. Retrieved from http://jmiap.ppj.unp.ac.id/index.php/jc e/article/view/400

Fitri. S,. Yusran R. (2020). Implementasi Kebijakan Rehabilitasi Penggunan Narkoba Pada Badan Narkotikanasional Provinsi Sumatera Barat. Vol 3 No,3,231-242. Retrieved from

http://jce.ppj.unp.ac.id/index.php/jce/a rticle/view/400

Handika, V,. Yusran. R. (2020). Implementasi program kotaku dalam upaya mengatasi permukiman kumuh dikabupaten lima puluh kota. Journal of civic education. Vol 3 no. 3.277-286. Retrieved from http://jce.ppj.unp.ac.id/index.php/articl e/view/397

Singgalang, (2017) Program Desaku Menanti Akhirnya Di-launching di Padang, Kamis, $9 \quad$ Maret $2017 \quad 13.00 \quad$ WIB https://hariansinggalang.co.id/programdesaku-menanti-akhirnya-di-launching-dipadang/

Peraturan Daerah kota Padang Nomor 1 tahun 2012 tentang Pembinaan Anak 
Vania Cynthia, Rahmadani Yusran I Evaluasi Program Desaku Menanti dalam Penanggulangan Gelandangan dan Pengemis di Kota Padang

Jalanan, Gelandangan, pengemis, Pengamen dan Pedagang Asongan.

Peraturan Pemerintah No.31 Tahun 1980 tentang Penanggulangan Gelandangan dan Pengemis. 